\title{
The effect of the qualitative coordination abilities on learning some attack skills and knowledge acquisition of water ball sport Ph. D. Mohammed Alazab Behiry Alazab
}

The huge expansion in scientific and human knowledge, and the information revolution which influenced all branches and fields of different sciences, made us cope with this development and revolution and try to mimic it so as to be part of modern societies. So, we should search for the best methods, techniques and use the latest means in teaching juniors in order to follow this progress.

Water ball sport requires junior's special abilities such as physical, skill, psychological and mental abilities that enjoy high levels which suit demands of technical performance in both kinds attack and defense. As junior's performance depends on what he possesses of ability to define the position of his body, the ball and the competitor either during stability and movement in order to be able to enjoy an efficient technical performance in different teaching and training conditions which depends mainly on the coordination abilities efficiency.
Mohammed Ali Elkot (2002) indicates that the planning to train water ball player should take into consideration the skill aspect, and also developing and modernizing the physical characteristics. The التوعنة النوعية trainings occupy a big part of the program during this stage. (1555: 6)

Vladimir Lyakh (2006) indicates that the coordination abilities are the possible coordinated and economical work between muscles, nerves, senses, balance, reaction, and speed adaption of situations. (11: 19)

This marks the importance of coordination abilities when juniors perform moves that require using more than one organ of the body in one time especially if these organs work in more than one direction in the same time. The accordance component requires a full cooperation between the muscular and nervous systems to be able to perform skills as perfect as possible especially the complicated ones which require merging skills of different kinds in one frame. 
Mohammed Sobhy Hassanin (2001) confirms that juniors who lose a certain portion of coordination abilities cause a great difficulty in reaching the performance mechanism in addition to the unbalance between movements and its resulted skills of difficult performance level. (114: 5)

Considering the rapid change nature of the physical and skill performance in water ball sport where various skills of different situations and dealing with one tool and players' movements in the limit of wide spaces and other limited spaces, it was necessary for specialists in the field of education and training of water ball to pay attention to the coordination abilities of water ball.

Knowledge is considered of the important fields as it is associated with the mental operations, and the learner's ability to acquire and use information and theoretical knowledge in different levels. The knowledge also plays an important role in the educational operation; we cannot imagine an educational unit without knowledge content. (78: 8)
Also the motor performance is the outcome of cooperation and integration of the knowledge aspect and the motor operations. The learner when learns a certain motor skill, he often acquire theoretical knowledge connected to it. Also, acquiring these knowledge contributes in increasing the effectiveness of motor learning. (108: 17)

Water ball is the only sport which is practiced inside the water by using the ball in a playground with special dimensions. Also the water ball is considered the strongest water sport as it requires a player of special specifications; as he should enjoy a high physical fitness and skilled in swimming. (21)

The researcher noticed that there are difficulties face juniors during performing some basic skills in water ball sport regarding the coordination between arms and legs. Also water resistance in it is huge which hinders the forward movement of the body. Water ball also needs moving different part of the body in one timing, which requires complicated and difficult movements because it contents bending and folding 
movements in different directions represented in the basic stage which are the hold, the pull, the push and the backward stage and also breathe and coordination. The most common mistakes that the juniors made concerning these skills which require the availability of coordination element is involving some unwanted muscle groups in performing the skills which cause disturbance in performing this skill and make it appear in a confused and not coordinated image.

The researcher sees the need to make an educational program and to know its effect on the different coordination abilities?? And some basic skills of water ball sport to raise the physical and coordination level and to shorten the time of mastering motor skills, then to raise the technical performance and knowledge level of juniors.

\section{Research aim}

This research aims to design an educational program to develop the qualitative coordination abilities and some basic skills of water ball sport, then to recognize:

-the effect of qualitative coordination abilities on learning some attack skills and the knowledge acquisition level in water ball.

\section{Research Hypothesis:}

There are statistically significant differences between the before and after measurements of the experimental group in the performance level of some attack skills (standing in the deep water - holding and catching the ball - swimming with the ball - passing the ball - aiming the ball) and the knowledge acquisition in water ball sport of Sporting Club Junior Team under (16) years in favor of the after measurement.

\section{Research Terms:}

\section{Coordination Abilities:}

"The cooperation

between the central nervous system and the musculoskeletal system (muscular and skeleton) in order to perform certain aimed movements". (57: 14)

The Ability to Estimate the Situation: *

"The junior's ability to estimate the changed situation of his body and other mobile things such as the ball and other people (colleagues and competitors)".

* A procedural definition. 
The Ability of Motor Connection:

"the junior's ability to assemble the total movements of part movements and complicated movements in ball games from the individual technique skills in a way that suits the requirements of skill performance.

The Ability to exert the maximum effort:

"The player's ability to perform his movements in a coordinated way concerning power degree, time and place in a way that serves achieving the desired aim. (132: 7)

The Ability to keep the balance:

'the junior's ability to keep his body in a certain position and to restore this position in case of deviation". The Rhythm Ability:

"The junior's ability to keep the good motor performance which shows the sound and visual senses and the performance form where he feels the internal rhythm and organizes it with the internal movement in order to achieve the motor aim."

The Ability of quick respond:

"the ability to perform movements quickly after hearing signs (verbal, visual) in order to achieve a motor work as quick reaction as possible". $(127,15)$

level:

The skill performance

"The degree which the athlete reaches of motor behavior resulted from the operation of acquisition and mastering the practiced activity movements so as to be performed in a way characterizes with accuracy, smooth and high degree of motivation to achieve the highest results with the least effort". (167: 2) Level *

Knowledge Acquisition

"The range of learner's absorption of information and knowledge of a certain subject and is expressed procedurally by the degrees' difference that expresses the change in the information test of water ball skills studied in the research".

Previous studies:

1- Glasauer (2003) (13) made a study titled "the coordination trainings in Basket ball" its aim was to recognize the effect of the coordination abilities on the performance level of basket ball juniors in "Hessen" province in Germany, the 
researcher used the experimental method in two experimental groups on a sample of (40) juniors divided into two groups; one of them under (14) years and its number was (20) and the other under (16) years and its number (20) juniors. One of the most important results was that trainings using the coordination abilities trainings led to an improvement in skill performance level of basket ball juniors. This improvement also was significantly affected by age which assures the necessity of continuing the development and improvement of these abilities since young age and to late adolescent stages.

2- $\quad$ Zak \& Duda (2003) (20) made a study titled "the coordination abilities level and the play efficiency of football juniors". This study aimed to define the effect of coordination abilities on the plan and skill performance of football juniors. The two researchers used the experimental method on a sample of (20) juniors under (17) years and the following coordination abilities were chosen (reaction speed - balance - special direction - the active visual coordination). The most important results the two researchers concluded was that the plan and skill performance level of football juniors depend on developing the coordination abilities.

3- Agnieszka (2005) made a study titled "the relation between the special motor coordination abilities and play efficiency of handball female juniors". The study aimed to test the special motor coordination abilities after the annual training plan and its relation with the effectiveness of Handball female juniors' performance. The researcher used the experimental method on a sample of 24 female juniors. The most important result was that there is a positive relation between the motor coordination abilities and the play efficiency; many researchers concluded this result but they did not present all the expected results. This was proven statistically and includes (the ability of motor diversity - the ability of motor adaptation). The female players also achieved very good results in the test that define the level of special motor coordination abilities.

4- Lyakh Vladimir (2006) (19) made a study titled "the 
conceptions and effectiveness of accordance training in sport field". Its aim was to consider the conceptions and effectiveness of accordance training in the sport field. The researcher used the descriptive method on a sample of (66) athletes participating in the athletic events (basketball volley - handball - football). One of the most important results was that there are five basic conceptions to improve the accordance in fighting sports and team (collective) games which are: the accordance training inside the physical preparation - teaching coordination abilities is one of the essential bases of all athletes' preparation contents teaching coordination abilities must be involved in technical preparation operations - the accordance preparation is an independent department inside the long term training system of the athlete.

5- Tarek Khalil Algamal (2008) (1) made a study titled "the effect of special coordination abilities on the skill performance level of field hokey juniors". Its aim was to recognize the special coordination abilities of hokey sport. The researcher used the descriptive method on a sample of (20) juniors. One of its most important results was that special coordination abilities of the age stage (12-9) years was represented in the ability to estimate the situation, the ability of motor connection, the ability to exert the suitable effort, the rhythm ability, the ability to adapt to the changed situations, there is a positive effect of special coordination abilities on some basic skills.

6- Mohammed Hamdy Abdel Hady (2009) (4) made a study titled "the effect of a training program to develop some coordination abilities on the effectiveness of spin skill and time of back swimming". Its aim was to design a program to develop the coordination abilities and to recognize its effect on some physical variables and the time of spin performance. The researcher used the experimental method on a sample of (30) swimmers. One of its most important results was that the suggested program using the coordination abilities positively affected the physical and skill variables of swimmers.

7- Hader Saied Abdel Azeem (2010) (10) made a study titled "the effect of using unilateral 
fins on some functional and coordination abilities of swimmers buds. Its aim was to recognize the effect of using unilateral fins on some functional and coordination abilities of swimmers buds. The researcher used the experimental method on a sample of (20) swimmers. One of its most important results was that the most important coordination abilities in the field of swimming sport represented in the ability to estimate the situation, the ability of the transitional speed, the ability of motor connection, the ability of balance, the ability of motor timing. The suggested program positively affected the functional and physical variables and the skill level of butterfly swimming. 8- Tarek Mohammed Elnosery (2013) (18) made a study titled "the effect of qualitative coordination abilities on learning some attack, defense and cognitive skills in handball. Its aim was to design an educational program to develop the qualitative coordination abilities, hence, to recognize the effect of qualitative coordination abilities on learning some attack, defense and knowledge skills in handball. The researcher used the experimental method on a sample of (40) students. One of its most important results was that the suggested program using the coordination abilities positively affected the skill variables and knowledge acquisition of the students.

The researcher made use of the previous studies in knowing how to design an educational program using some coordination abilities in order to teach some attack skills studied in the research, and in testing the sample, the research method, the used tools and the suitable statistical method.

Research procedures:

Research method:

The researcher used the experimental method using the experimental design of one group following the before \& after measurements as it suit the nature of the research.

Research Sample \& Society:

The research society included the Sporting Club juniors under 16 years, it was (32) juniors, then the researcher chose the basic research sample deliberately of (20) juniors. (12) Juniors were pulled out for the pilot study and to perform the scientific interactions on 
them, and table (1) shows the description of research sample.

Table (1)

The description of research society \& sample

\begin{tabular}{c|c|c|c}
\hline \hline Statement & $\begin{array}{c}\text { Research } \\
\text { society }\end{array}$ & $\begin{array}{c}\text { Research } \\
\text { basic sample }\end{array}$ & Pilot study \\
\hline \hline $\begin{array}{c}\text { Sporting Club juniors } \\
\text { under 16 years }\end{array}$ & 32 & 20 & 12 \\
\hline \hline
\end{tabular}

Coherence of research sample:

The researcher made sure of the Equinoctial distribution of research personnel of the basic

and pilot samples in the growth rates (age - height - weight), as table (2) shows.

\section{Table (2)}

The coherence of research sample (experimental - pilot) in the $\mathrm{N}=32$ growth variables studied in the research

\begin{tabular}{|c|c|c|c|c|c|c|}
\hline variables & $\begin{array}{c}\text { Measure } \\
\text { unit }\end{array}$ & means & $\begin{array}{l}\text { Standard } \\
\text { deviation }\end{array}$ & medium & $\begin{array}{c}\text { Coefficient } \\
\text { of torsion }\end{array}$ & $\begin{array}{l}\text { Coefficient } \\
\text { of kurtosis }\end{array}$ \\
\hline Time age & Year & 10.2r/ & 10 & $.0 . \xi$ & $r .7 \cdot \varepsilon$ & r. $\cdot 4-$ \\
\hline $\begin{array}{c}\text { Total } \\
\text { body } \\
\text { height }\end{array}$ & $\mathrm{Cm}$ & $|v| . v 19$ & $|v|$ & r. \&พq & $\cdot \wedge \varepsilon \varepsilon$ & $\therefore$. Aro- \\
\hline weight & $\mathrm{Kg}$ & $v \cdot .704$ & $v_{1}$ & 1.110 & $. .7 \cdot 1-$ & $.1 \% \varepsilon$ \\
\hline $\begin{array}{l}\text { Table } \\
\text { coefficie } \\
\text { research } \\
\text { between }\end{array}$ & $\begin{array}{l}\text { sho } \\
\text { of } \\
\text { ciety } \\
604\end{array}$ & that & $\begin{array}{l}\text { the } \\
\text { of } \\
\text { was } \\
\text { the }\end{array}$ & \multicolumn{3}{|c|}{$\begin{array}{l}\text { variables (time age }- \text { height }- \\
\text { weight) which is less than }(+3 \text {, } \\
-3) \text { which indicates the } \\
\text { coherence in these variables. }\end{array}$} \\
\hline
\end{tabular}

\section{Table (3)}

The research sample coherence (experimental) in the growth variables studied in the research $\mathrm{N}=\mathbf{2 0}$

\begin{tabular}{|c|c|c|c|c|c|c|}
\hline variables & $\begin{array}{c}\text { Measure } \\
\text { unit }\end{array}$ & means & $\begin{array}{l}\text { Standard } \\
\text { deviation }\end{array}$ & medium & $\begin{array}{c}\text { Coefficient } \\
\text { of torsion }\end{array}$ & $\begin{array}{l}\text { Coefficient } \\
\text { of kurtosis }\end{array}$ \\
\hline Time age & Year & 10.ro. & 10 & $\because \leqslant \wedge 9$ & Y. I $\leqslant 7$ & $1 . \vee 19-$ \\
\hline $\begin{array}{c}\text { Total body } \\
\text { height }\end{array}$ & $\mathrm{Cm}$ & IVY.1.. & $1 V 1.0$ & r.VOI & $.70 \xi$ & $1 . \varepsilon r r_{-}$ \\
\hline weight & $\mathrm{Kg}$ & $v \cdot .7 \cdot$ & vi & $1 . \vee \wedge 9$ & $. .7 V 1-$ & $\cdot r \cdot q$ \\
\hline
\end{tabular}


Table (3) shows that the coefficient of torsion of research society personnel was between ((2.146 ،-0.671) in the variables (time age - height - weight) which is less than $(+3,-3)$ which indicates the coherence in these variables.

Means \& tools of data gathering:

- Reference analysis, personal interview, objective notes, tests.

- Restmeter to measure height and weight.

- Medical balls - water balls measure tape.

- Water ball playground.

- Wall عقل flags.

First: Tests of Coordination abilities: (appendix 3)

The researcher made a survey study of the scientific references, researches and previous studies, Glasauer (2003) (13), Lyakh Vladimir (2006) (19), Mohammed Hamdy Abdel Hady (2009) (4), Hader Saied Abdel Azeem (2010) (10), Tarek Mohammed Alnosery (2013) (18), he defined the special coordination abilities of water ball, and displayed them on (5) experts in the field of swimming and water ball whose their experience in this field is not less than 10 years (appendix 1) to define the most important coordination abilities which suits the attack basic skills studied in the research (appendix 2).

- The ability of motor rhythm (the test of motor rhythm and its measure unit is the degree). "The researcher's design.

- The ability of motor connection (the test of complicated skill and its measure unit is the degree). "The researcher's design.

- The ability of exerting the maximum effort (the test of throwing a medical ball of 800 gm from stability and its measure unit is the meter). (18)

The ability of keeping the balance (the test of jumping with both legs inside the hexagonal form "the dynamic balance" and its measure unit is the second). (16)

The ability of organization and motor direction (the test of jumping the robe and its measure unit is the number). (5)

Second: the evaluation form of skill performance level. (Appendix 4)

According to the experts' opinion in this field (Appendix 4), the measurement components of the skill performance level were 
defined, and also the degree of each skill, the measurement degree as a whole, and the degrees were distributed as shown in the following table:

Table (4)

The measurement degrees' distribution of skill level

\begin{tabular}{c|c|c}
\hline \hline No. & $\begin{array}{c}\text { Measurement skills of skill performance } \\
\text { level }\end{array}$ & Degree \\
\hline \hline 1 & The skill of standing in deep water & 5 \\
\hline 2 & The skill of holding and catching the ball & 5 \\
\hline 3 & The skill of swimming with the ball & 3 \\
\hline 4 & Skill of Passing & 4 \\
\hline 5 & Skill of aiming & 5 \\
\hline \hline
\end{tabular}

Third: knowledge acquisition. (Appendix 5)

The researcher used in injuries, game history, gathering data the specialized scientific references in the field of water ball, and the specialized studies which were made in the field of building knowledge tests in physical education in general and in water ball in particular to define the aims required to be measured in light of the following: (warming, common

psychological aspect, play rules, basic skills). As the researcher displayed the test exes on a group of experts in curriculums, teaching methods, swimming and athletic psychology who have not less than 15 years of experience in this field (enclose 6), as shown in table (5)

Table (5)

The relative importance of knowledge acquisition axes

\begin{tabular}{c|c|c}
\hline \hline Axis no. & Axes & Expert degree \\
\hline \hline 1 & Warming & $\%$. \\
\hline 2 & Common injuries & $\%$ v... \\
\hline 3 & Game history & $\% v_{0}$ \\
\hline 4 & Psychological aspect & $\%$. . . \\
\hline 5 & Play rules & $\% 1 .$. \\
\hline 6 & Basic skills & $\%$... \\
\hline \hline
\end{tabular}


Table (5) shows that all the axes obtained high ratio between $75 \%$ to $100 \%$ according to experts' opinion. 1- The primary form of the test was formed and the test questions took into consideration

(comprehensiveness - clarity of expression - suitable for research sample level scientific accuracy - measuring the aims of program skills content - briefing - that the word does not bear more than one meaning).

2- The researcher used in forming the test phrases two forms of phrases; the first is true and false, the second is multiple choices.

3- The test was displayed on a group of experts (enclose 6 ) in order to define the valid vocabulary and to exclude the inappropriate ones, and to make sure that the test questions suit the students' level and that it includes all knowledge learning aspects of skills studied in the research. The necessary adjustments were made in light of the experts' opinions, so the test terms became (53) in its final form, as shown in table (6)

Table (6)

Acquisition test axes and the number of phrases in each axis

\begin{tabular}{|c|c|c|c|c|c|}
\hline No. & Axes & $\begin{array}{c}\text { No. of } \\
\text { true or } \\
\text { false } \\
\text { phrases }\end{array}$ & $\begin{array}{c}\text { No. of } \\
\text { multiple } \\
\text { choice } \\
\text { phrases }\end{array}$ & Total & $\begin{array}{c}\text { Axis } \\
\text { numbers }\end{array}$ \\
\hline 1 & Warming & ○ & $r$ & $\wedge$ & $1-1$ \\
\hline 2 & $\begin{array}{l}\text { Common } \\
\text { injuries }\end{array}$ & - & 7 & 7 & $1 \varepsilon-9$ \\
\hline 3 & Game history & 1 & 0 & 1 & r. -10 \\
\hline 4 & $\begin{array}{l}\text { Psychological } \\
\text { aspect }\end{array}$ & $\wedge$ & $\varepsilon$ & ir & $r r-r$ \\
\hline 5 & Play rules & 9 & $\varepsilon$ & ir & \&o- $r r$ \\
\hline 6 & Basic skills & - & 8 & 8 & $46-53$ \\
\hline & Total & 23 & 30 & 53 & \\
\hline
\end{tabular}

The scientific interactions of knowledge acquisition

The knowledge acquisition was applied on the pilot sample; its number was (12) juniors from Sporting Club juniors under 16 years and from outside the basic research sample on 
Saturday 25/5/2013. The researcher corrected the test and calculated thee degree which the junior obtained, then he arranged the degrees descending according to degrees total of each junior of the test. The researcher was

Table (7)

The coefficient of distinction \& difficulty of knowledge acquisition $\mathrm{N}=12$

\begin{tabular}{|c|c|c|c|c|c|}
\hline No. & $\begin{array}{l}\text { Distinction } \\
\text { coefficient }\end{array}$ & $\begin{array}{l}\text { Difficulty } \\
\text { coefficient }\end{array}$ & No. & $\begin{array}{l}\text { Distinction } \\
\text { coefficient }\end{array}$ & $\begin{array}{l}\text { Difficulty } \\
\text { coefficient }\end{array}$ \\
\hline 1 & *. . & $* .0 \vee 7$ & 29 & $* .007$ & $* . .7 \leqslant Y$ \\
\hline 2 & *..VTY & $* .771$ & 30 & $*$. * . & $* . \leqslant 09$ \\
\hline 3 & $* .0 \wedge Y$ & $* .0 \vee 9$ & 31 & $* .700$ & $* . V 10$ \\
\hline 4 & $* .0 \wedge 1$ & *. & 32 & *. .VYT & $* .000$ \\
\hline 5 & *. . & $* .71 \wedge$ & 33 & $* .799$ & $* . \leqslant 9 \Gamma$ \\
\hline 6 & *.AYr & $* . \leqslant \wedge 0$ & 34 & *. . $\leqslant T \Gamma$ & *. rq7 \\
\hline 7 & $* . \wedge 79$ & $* . \Sigma 7 r$ & 35 & *.Yו & $* . . \leqslant \leq \wedge$ \\
\hline 8 & $* .7 \leq 0$ & *. . $\leqslant$ I & 36 & $* . \leqslant .0$ & $* . .291$ \\
\hline 9 & $* . \wedge \vee \wedge$ & *. .V7. & 37 & $* . .7 \leqslant \mu$ & $* . \_O Y$ \\
\hline 10 & $* .7 . \varepsilon$ & $* .777$ & 38 & $* . \wedge 77$ & $* .0 \vee 7$ \\
\hline 11 & $* .070$ & *..V9 & 39 & $* .0 \leqslant 9$ & $* .7 \vee 7$ \\
\hline 12 & $* . .597$ & $* .7 \cdot \Lambda$ & 40 & $* . . \leqslant 90$ & $* .719$ \\
\hline 13 & $* .00 \Lambda$ & $* .7 . Y$ & 41 & $* .099$ & $* . \wedge 01$ \\
\hline 14 & $* . V \cdot \varepsilon$ & $* .7 \vee 9$ & 42 & $* . . \wedge \mathrm{V}$ & $* . V \vee \leqslant$ \\
\hline 15 & *. . TY & $* .7 \leq \leqslant$ & 43 & *. .VY. & *. Tro \\
\hline 16 & $* .0 \vee \wedge$ & $* . V 10$ & 44 & $* . \Sigma V Y$ & $* .7 \vee 0$ \\
\hline 17 & $* .7 .1$ & $* . . V \vee \varepsilon$ & 45 & $* .01 Y$ & $* . V I T$ \\
\hline 18 & $* . .7 \leqslant \mu$ & $* . \vee V \leqslant \leqslant$ & 46 & *.OT & $* . V \leq 1$ \\
\hline 19 & $* . V 71$ & $* . \wedge 11$ & 47 & $* .001$ & *. VTr \\
\hline 20 & $* . V$. & $* . \vee \wedge q$ & 48 & $* .0 \leq 7$ & $* .799$ \\
\hline 21 & $* .719$ & $* . . \wedge \wedge 7$ & 49 & $* .71 \leqslant$ & $* . V \cdot \varepsilon$ \\
\hline 22 & $* .070$ & $* .71$. & 50 & *. .T. & $* . . V \leqslant Y$ \\
\hline 23 & $* .7 \leq 1$ & *. . 199 & 51 & $* . .7 \leq V$ & $* . V \leq$ \\
\hline 24 & $* .001$ & $* .0 \leqslant \Gamma$ & 52 & $* .07 V$ & $* . V I$. \\
\hline 25 & $* . .7 \cdot r$ & $* . V \leqslant 1$ & 53 & $* .077$ & *I.TY \\
\hline 26 & $* .099$ & $* .79 V$ & & & \\
\hline 27 & $* .711$ & *.IYr & & & \\
\hline
\end{tabular}




\begin{tabular}{|c|c|c|c|c|c|c|}
\hline \multicolumn{2}{|c|}{$* .7 \Gamma 0$} & \multicolumn{2}{|c|}{$* \cdot V \cdot 1$} & & & \\
\hline \multicolumn{4}{|c|}{$\begin{array}{l}\text { Table (6) shows that the } \\
\text { estimation of distinction } \\
\text { coefficient and difficulty } \\
\text { coefficient of knowledge } \\
\text { acquisition axes questions has } \\
\text { a suitable distinction power, } \\
\text { which urged the researcher to } \\
\text { use the test in measuring the } \\
\text { knowledge acquisition. } \\
\text { Reliability calculation }\end{array}$} & \multicolumn{3}{|c|}{$\begin{array}{l}\text { The Reliability of knowledge } \\
\text { acquisition was performed on } \\
\text { the same previous pilot study } \\
\text { sample using the method of } \\
\text { applying the test then retest } \\
\text { under the same conditions of } \\
\text { the first application, in the } \\
\text { period from } 26 / 5 \text { to } 2 / 6 / 2013 \text {, } \\
\text { as shown in table (8) }\end{array}$} \\
\hline \multicolumn{7}{|c|}{$\begin{array}{c}\text { Table (8) } \\
\text { Knowledge Acquisition Reliability } \\
\mathrm{N}=12\end{array}$} \\
\hline \multirow[t]{2}{*}{ Test } & \multicolumn{2}{|c|}{$\begin{array}{c}\mathbf{1}^{\text {st }} \\
\text { application }\end{array}$} & \multicolumn{2}{|c|}{$\begin{array}{c}\mathbf{2}^{\text {nd }} \\
\text { application }\end{array}$} & \multirow{2}{*}{$\begin{array}{c}\text { Difference } \\
\text { between } \\
\text { applications }\end{array}$} & \multirow{2}{*}{$\begin{array}{l}\text { Coefficient } \\
\text { correlation }\end{array}$} \\
\hline & $\mathrm{M}$ & $\mathrm{D} \pm$ & M & $\mathrm{D} \pm$ & & \\
\hline $\begin{array}{c}\text { Knowledge } \\
\text { test }\end{array}$ & . & r. $\{\pi\}$ & ro.vo. & r.r. & - & $* .974$ \\
\hline
\end{tabular}

(R)

Table value at level $0.05=$ 0.576

Table (8) shows that there is a statistically significant correlation at level 0.05 between the two applications of knowledge acquisition, which indicates the Reliability of the test in measuring what it was made to measure.

\section{Validity Calculation}

The validity was calculated by the internal consistency validity via calculating the correlation coefficient between the degree of each phrase and the total degree of the test, on Monday 3/6, as shown in table (9) 
Table (9)

Knowledge acquisition validity

\begin{tabular}{|c|c|c|c|c|c|c|c|}
\hline No. & $\begin{array}{c}\text { Correlation } \\
\text { coefficient }\end{array}$ & No. & $\begin{array}{l}\text { Correlation } \\
\text { coefficient }\end{array}$ & No. & $\begin{array}{l}\text { Correlation } \\
\text { coefficient }\end{array}$ & No. & $\begin{array}{l}\text { Correlation } \\
\text { coefficient }\end{array}$ \\
\hline 1 & $* .7 \vee q$ & 18 & $* .079$ & 35 & $* . \wedge\urcorner$. & 52 & $* . .7 V I$ \\
\hline 2 & *. & 19 & $* \tau . r \leqslant$. & 36 & $* . \wedge 19$ & 53 & $* . \leqslant 0 \leqslant$ \\
\hline 3 & $* .047$ & 20 & $*\rceil .1 . \varepsilon$ & 37 & $* . \vee 0 \leq$ & & \\
\hline 4 & $* .7 \vee \wedge$ & 21 & $* 0.9 \wedge 7$ & 38 & $* . V 74$ & & \\
\hline 5 & $* . \wedge \varepsilon$. & 22 & $* .0 \leqslant \wedge$ & 39 & $* . \wedge \cdot 1$ & & \\
\hline 6 & $* . \wedge Y I$ & 23 & $* .70 \mathrm{~V}$ & 40 & $* . V T r$ & & \\
\hline 7 & *. * & 24 & *. .АT० & 41 & $* . V \cdot \Sigma$ & & \\
\hline 8 & $* . \vee 00$ & 25 & $* . \wedge 1$. & 42 & $* . \vee \vee$. & & \\
\hline 9 & $* .7 \leqslant 0$ & 26 & $* .7 \vee 9$ & 43 & $* . \Delta \mu r$ & & \\
\hline 10 & $* . V \Gamma V$ & 27 & $* .771$ & 44 & $* . V 74$ & & \\
\hline 11 & $* . \vee \cdot 1$ & 28 & $* . V \cdot Y$ & 45 & $* .7 \vee 9$ & & \\
\hline 12 & $* . . V Y Y$ & 29 & $* . \vee \backslash 1$ & 46 & $* . .7 \leqslant \wedge$ & & \\
\hline 13 & $* .7 \leqslant 9$ & 30 & $* . V T Y$ & 47 & $* . V T_{0}$ & & \\
\hline 14 & $*$. *VOr & 31 & $* . \wedge \uparrow ।$ & 48 & $* . V T Y$ & & \\
\hline 15 & $* . \vee V \leqslant$ & 32 & $* . \vee \vee 79$ & 49 & $* . \wedge \ldots$ & & \\
\hline 16 & $* .704$ & 33 & $* . .7 Y \Lambda$ & 50 & $* . . \wedge \leqslant Y$ & & \\
\hline 17 & $* . V R T$ & 34 & $*$. VOY & 51 & $* . \vee r q$ & & \\
\hline
\end{tabular}

(R) Table value at level $0.05=0.576$

Table (9) shows that the correlation coefficient between each phrase and the total degree of the axis and between each axis and the total degree of the test is statistically significant at level 0.05 , which indicates the test validity for what it was put. Thus, the test in its final image is ready to be applied on the basic research sample, was its phrases included 83 phrases, and also the correction key (appendix $5)$.

\section{The pilot studies:}

1- The $1^{\text {st }}$ pilot study in the period from $4 / 6$ to $6 / 6 / 2013$

The study aimed to make the assistant and the juniors understand the conceptions and nature of the general and special coordination abilities elements and the essential differences between the coordination abilities and the 
physical fitness elements in the method of directed different development and training and also to define the general aims of the program and to define the date of applying the program studied in the research.

This study led to the following results:

- To recognize the coordination abilities from the applied aspect and the patterns of general coordination abilities trainings in different activities and the patterns of special coordination abilities trainings if water ball sport.

- The assistants' efficiency in recognizing the mistakes than juniors may commit during their application of the special coordination abilities in water ball sport.

2- The $2^{\text {nd }}$ pilot study in the period from $8 / 6$ to $10 / 6 / 2013$

The study aimed to:

- Make the executive program of coordination abilities with its stages and organize the execution of the coordination abilities with its trainings according to the difficulty degree and to apply it on the juniors and to know their respond according to their age stage.

Recognize the most important used tests (coordination abilities- skill performance level) which will be applied after gathering them through the reference analysis, taking the experts' opinions, periodical magazines and searching via the internet about topics related to water ball sport.

\section{The Scientific Interactions} of the used tests:

\section{First: validity}

The researcher used the part comparison validity between the high \& low degrees by organizing the degrees descending from the highest to the lowest, and to find the difference between the personnel of the pilot study sample of (12) juniors, on Tuesday 11/6/2013. 
Table (10)

The Arithmetic Means, the Standard Deviation and ( $T)$ value and its significance between the lowest $\&$ the highest spring of pilot $\mathrm{N}=12$

\section{study sample}

\begin{tabular}{|c|c|c|c|c|c|c|}
\hline \multirow{3}{*}{ variables } & \multirow{2}{*}{\multicolumn{2}{|c|}{$\begin{array}{c}\text { Lowest } \\
\text { spring }\end{array}$}} & \multirow{2}{*}{\multicolumn{2}{|c|}{$\begin{array}{c}\text { Highest } \\
\text { spring } \\
\mathrm{N}=3\end{array}$}} & \multirow{3}{*}{$\begin{array}{c}\text { Difference } \\
\text { between } 2 \\
\text { averages }\end{array}$} & \multirow{3}{*}{$\begin{array}{c}(\mathrm{T}) \\
\text { calculated } \\
\text { value }\end{array}$} \\
\hline & & & & & & \\
\hline & $\mathrm{M} /$ & $\mathrm{D} \pm$ & $\mathrm{M} /$ & $\mathrm{D} \pm$ & & \\
\hline $\begin{array}{l}\text { Motor } \\
\text { rhythm }\end{array}$ & 7. Trr & $\because Y \wedge q$ & ร. TTV &. $.0 \mathrm{VV}$ & r.17V & A. YYY \\
\hline $\begin{array}{c}\text { Complicated } \\
\text { skill test }\end{array}$ & $11 . \ldots$ & $1 . \cdots$ & V. TTV &. $.0 \mathrm{VV}$ & r.rr & $v_{0} \cdot v_{1}$ \\
\hline $\begin{array}{c}\text { Throw a } \\
\text { medical ball } \\
\text { of } 800 \mathrm{gm} \\
\text { from } \\
\text { stability }\end{array}$ & M.Y.. & $\because V Y I$ & $10 . \cdots$ & $1 . \cdots$ & r.r.. & T. rON \\
\hline $\begin{array}{l}\text { Jumping } \\
\text { both legs } \\
\text { inside the } \\
\text { hexagonal } \\
\text { form }\end{array}$ & rl.... & $1 . \cdots$ & IV.TEr & .001 & r.rov & V.IVq \\
\hline $\begin{array}{c}\text { Robe } \\
\text { jumping }\end{array}$ & ร. TTV &. $.0 \mathrm{VV}$ & r.17V &. Vฯ\& & Y.o.. & $7 . r 97$ \\
\hline $\begin{array}{c}\text { Skill of } \\
\text { standing in } \\
\text { deep water }\end{array}$ & r.17V & $\because \curlyvee \wedge q$ & $1.07 \mathrm{~V}$ & $\cdot . \varepsilon \cdot \varepsilon$ & $1.7 \ldots$ & $V . \wedge 91$ \\
\hline $\begin{array}{l}\text { The skill of } \\
\text { Holding \& } \\
\text { catching the } \\
\text { ball }\end{array}$ & r.Arr & $\because Y \wedge q$ & $1 . v \cdots$ & $.1 \ldots$ & 1.1. & $9 . \cdot \wedge V$ \\
\hline $\begin{array}{c}\text { Skill of } \\
\text { swimming } \\
\text { with the ball }\end{array}$ & r.Arr & $\because$ Y^q & 1.Ar & $\because Y \wedge 9$ & $1 . \cdots$ & 7... \\
\hline Passing skill & r. TTV &. $.0 \mathrm{VV}$ & $1.77 V$ &. $.0 \mathrm{VV}$ & $1 . \cdots$ & r.... \\
\hline
\end{tabular}




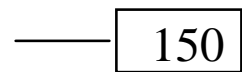

\begin{tabular}{|c|c|c|c|c|c|c|}
\hline \multirow{3}{*}{ variables } & \multirow{2}{*}{\multicolumn{2}{|c|}{$\begin{array}{c}\begin{array}{c}\text { Lowest } \\
\text { spring }\end{array} \\
\mathrm{N}=3\end{array}$}} & \multirow{2}{*}{\multicolumn{2}{|c|}{$\begin{array}{c}\text { Highest } \\
\text { spring } \\
\mathrm{N}=3\end{array}$}} & \multirow{3}{*}{$\begin{array}{c}\text { Difference } \\
\text { between } 2 \\
\text { averages }\end{array}$} & \multirow{3}{*}{$\begin{array}{c}(\mathrm{T}) \\
\text { calculated } \\
\text { value }\end{array}$} \\
\hline & & & & & & \\
\hline & $\mathrm{M} /$ & $\mathrm{D} \pm$ & $\mathrm{M} /$ & $\mathrm{D} \pm$ & & \\
\hline Aiming skill & r. 17. &.$r 90$ & س & $\because r \wedge q$ & I.AYV & $1 \cdot . \wedge \varepsilon \wedge$ \\
\hline
\end{tabular}

(T) Table value at morale level consequently measure what it $(0.05)=2.776$ and free degree 4

Table (4) shows that there are statistically significant differences at morale level (0.05) between the lowest \& highest spring in the coordination \& skill abilities tests, which indicates that the tests enjoy a high degree of validity and have the ability to show the differences and was put for and are valid to be used.

\section{Second: Test Reliability}

To find the test reliability coefficient, the researcher applied the tests then retest with a time interval of 3 days, in the period from $12 / 6$ to $15 / 6 / 2013$. The researcher used the simple Liberson coefficient correlation between the results of the $1^{\text {st }} \& 2^{\text {nd }}$ applications. 
Table (11)

The Validity of skill \& coordination abilities tests studied in the research

$\mathrm{N}=2$

\begin{tabular}{|c|c|c|c|c|c|c|c|c|}
\hline \multirow{3}{*}{ variables } & \multirow{2}{*}{\multicolumn{2}{|c|}{$\begin{array}{c}\text { Lowest spring } \\
\mathrm{N}=3\end{array}$}} & \multirow{2}{*}{\multicolumn{2}{|c|}{$\begin{array}{c}\text { Highest spring } \\
\mathrm{N}=3\end{array}$}} & \multirow{3}{*}{$\begin{array}{c}\text { Difference } \\
\text { between } 2 \\
\text { averages }\end{array}$} & \multirow{3}{*}{$\begin{array}{c}(\mathrm{T}) \\
\text { calculated } \\
\text { value }\end{array}$} & \multirow{3}{*}{$\begin{array}{c}(\mathrm{R}) \\
\text { value }\end{array}$} & \multirow{3}{*}{$\begin{array}{c}\text { Self- } \\
\text { validity }\end{array}$} \\
\hline & & & & & & & & \\
\hline & M/ & $\mathrm{D} \pm$ & M/ & $\mathrm{D} \pm$ & & & & \\
\hline $\begin{array}{l}\text { Motor } \\
\text { rhythm }\end{array}$ & $0 .\{\leqslant \wedge$ &. .191 & $0.0 \wedge r$ & . var & $0.1 \% 4-$ & צror & *. .941 & .970 \\
\hline $\begin{array}{l}\text { Complex } \\
\text { skill test }\end{array}$ & V.A11 & דra & $\Lambda . \cdot 7 \Lambda$ & r & . YO.- & $1 . .1 \mathrm{~V}$ & *. . ^9r & $\because 9 \leqslant 0$ \\
\hline $\begin{array}{l}\text { Throw a } \\
\text { medical } \\
\text { ball of } \\
800 \mathrm{gm} \\
\text { from } \\
\text { stability }\end{array}$ & $|V .07|$ & 1.101 & $|V . \wedge I|$ & ..$\wedge r \varepsilon$ & $\cdot$.ro.- & $\cdot \Delta r r$ & $* . .100$ & $.9 Y \varepsilon$ \\
\hline $\begin{array}{l}\text { Jumping } \\
\text { both legs } \\
\text { inside the } \\
\text { hexagonal } \\
\text { form }\end{array}$ & IV.AYA & $\cdot$ VIV & IV.OAr &. .779 & $\cdot r \leqslant \varepsilon$ & 1.179 & *. .va1 & $\cdot . \wedge 9 \varepsilon$ \\
\hline $\begin{array}{c}\text { Robe } \\
\text { jumping }\end{array}$ & r.sTr & $\cdot$ VAr & r. $01 \mathrm{~V}$ & $\cdot . v \cdot 1$ & $\cdot$.1ro- &. .001 & $* .911$ & $\cdot 901$ \\
\hline $\begin{array}{l}\text { Skill of } \\
\text { standing } \\
\text { in deep } \\
\text { water }\end{array}$ & $r \cdot r \cdot \Lambda$ &. $.70 \mathrm{~V}$ & Y.\&IV & .010 & $\cdot 1 \cdot 1-$ & $\cdot .7 \cdot 9-$ & *. .9rq & $\cdot 97 \varepsilon$ \\
\hline $\begin{array}{c}\text { The skill } \\
\text { of } \\
\text { Holding } \\
\& \\
\text { catching } \\
\text { the ball }\end{array}$ & $r .119$ & . & r.YO. &. .499 & - & $1 . \cdots 1-$ & $* . .9 \cdot r$ & .90 . \\
\hline $\begin{array}{c}\text { Skill of } \\
\text { swimming } \\
\text { with the } \\
\text { ball }\end{array}$ & r.MIO & Tr r & r.\&IV &..$r 09$ & $\cdot 1 \cdot Y-$ & $\cdot .9 \cdot 0-$ & * * * & $\because q r q$ \\
\hline $\begin{array}{c}\text { Passing } \\
\text { skill }\end{array}$ & r.YOI &. . & r.rar & $\cdot . \leqslant 0$. & $\because \cdot \varepsilon Y_{-}$ & $\cdot r \cdot v-$ & $*_{.} .9 \leqslant 9$ & $\cdot 9 \vee \varepsilon$ \\
\hline $\begin{array}{l}\text { Aiming } \\
\text { skill }\end{array}$ & r.r.V & $\cdot$ Vr. & r.rq. & .711 & $\because \wedge r-$ & $\cdot \varepsilon \mid Y-$ & *.91ई & .901 \\
\hline
\end{tabular}

(r) Table value at $(0.05)=0.576$ and free degree 10

(T) Table value at $(0.05)=$ Table (11) shows that there is a 2.201 and free degree 11 statistically significant correlation between the $1^{\text {st }} \&$ 
$2^{\text {nd }}$ applications and the correlation coefficient of research variables were between $(0.931-0.798)$ which indicates the reliability of skill $\&$ motor abilities tests studied in the research.

\section{The suggested educational} program:

Steps of building the program:

- $\quad$ The suggested program aim to try to make Sporting Club juniors under 16 years (research sample) reach the highest skill level in some basic skills of water ball.

- To define the content that includes the coordination trainings in the skill direction.

Bases of making the program:

- $\quad$ To define program aims.

- $\quad$ To define the level of the primary motor skills of the juniors.

The level of the special coordination abilities of water ball after its definition.

- $\quad$ The stages of executing the coordination abilities program (the $1^{\text {st }}, 2^{\text {nd }}$, and $3^{\text {rd }}$ stages).

- The available times for education, training and the time division of the program according to the stages.
- $\quad$ To define the number of educational \& training units.

\section{Program planning:}

- The program time plan was defined as (6) weeks, (4) units per week.

- The time of the unit (120) min.

The scientific bases that should be taken into consideration when putting the coordination trainings:

- $\quad$ Putting the trainings in a scientific and accurate way.

- The trainings gradation regarding the number of parts participating in the performance.

- The trainings diversity concerning the volume and the degree and also the used tools and changing the training environment.

- The comprehensive trainings to develop all elements of coordination abilities.

- To pay attention to the sequence and the special connection of the special trainings concerning each one of the coordination abilities to achieve the maximum benefit using the least effort.

- The chosen trainings should resemble the motor path of each motor skills and the actual performance way in 
order to avoid any disturbance during the performance.

- $\quad$ Training should be taken from the basic skills of water ball and to help to improve the physical \& skill level.

The training should be related to the same muscle group that work in the basic skills of water ball.

- These aims should cope with the research sample needs in the technical \& coordination abilities.

- The suggested program is subject to the accurate technical supervision and continuous correction.

- To take into consideration the individual differences and the diversification in the trainings.

In light of the mentioned above, the research defined a group of qualitative coordination trainings to improve the skill performance of the sample studied in the research.

The content of the daily training unit:

- The introductory part (warm-up) (physical trainings in the same direction of the coordination abilities) $25 \mathrm{~min}$.

- The main part (the suggested coordination skill trainings studied in the research).

- The final part (the calming and the stretches) 5 min.

The executive steps of the program:

The Before Measurement:

The Before measurements were performed on Sunday $16 / 6 / 2013$ of the experimental group in the coordination \& skill tests \& the knowledge acquisition on the Sporting Club Juniors under 16 years.

\section{Program execution:}

The suggested program was applied on the experimental group (appendix 7) for (6) weeks in the period from 17/6 to $29 / 7 / 2013$, as (4) units per week, and the each unit time was (120) min.

\section{The After measurement:}

The after measurements were performed on Tuesday $30 / 7 / 2013$ on the experimental group in the knowledge, coordination and skill tests and under the same conditions of the $1^{\text {st }}$ application.

\section{Statistical Treatments:}

The researcher used the following statistical treatments using the computer statistical program SPSS, and calculated:

- The Arithmetic Means.

- $\quad$ The Medium. 
- The Standard Deviation.

- The coefficient of

torsion.

- The coefficient of kurtosis (flattening).
- Ca2 value.

- T- Test.

\section{Results Display \&}

Discussion:

\section{Table (12)}

The differences significance between the before $\&$ after measurements of the experimental group in the coordination abilities studied in the research

\begin{tabular}{|c|c|c|c|c|c|c|c|c|}
\hline \multirow[t]{2}{*}{ variables } & \multirow{2}{*}{$\begin{array}{c}\text { Measure } \\
\text { unit }\end{array}$} & \multicolumn{2}{|c|}{$\begin{array}{c}\text { Before } \\
\text { measurement }\end{array}$} & \multicolumn{2}{|c|}{$\begin{array}{c}\text { After } \\
\text { measurement }\end{array}$} & \multirow{2}{*}{$\begin{array}{l}\text { Difference } \\
\text { average }\end{array}$} & \multirow{2}{*}{$\begin{array}{c}(\mathrm{T}) \\
\text { value }\end{array}$} & \multirow{2}{*}{$\begin{array}{l}\text { Improvement } \\
\text { rates }\end{array}$} \\
\hline & & $\mathrm{M} /$ & $\mathrm{D} \pm$ & $\mathrm{M} /$ & $\mathrm{D} \pm$ & & & \\
\hline $\begin{array}{l}\text { Motor } \\
\text { rhythm }\end{array}$ & Degree & 7. $\cdot \wedge \mathrm{V}$ & $\cdot .9 \cdot 8$ & 1.0 .9 & $\cdot v \varepsilon \varepsilon$ & Y.\&YY- & *II.rIE & $\%$ \%q.v৭ \\
\hline $\begin{array}{l}\text { Complicated } \\
\text { skill test }\end{array}$ & Degree & $9.1 \ldots$ & .971 & Ir.VVo & $1 . r 91$ & r.TVo- & 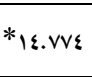 & $\% \varepsilon \cdot r \wedge$ \\
\hline $\begin{array}{c}\text { Throw a } \\
\text { medical ball } \\
\text { of } 800 \mathrm{gm} \\
\text { from stability }\end{array}$ & Meter & 17. Orr & $1 . r \leqslant 7$ & $r \cdot \Delta T_{I}$ & $1 . . r 9$ & $\varepsilon . \Gamma \cdot \Lambda-$ & $*_{1}$..人т. & $\%$ \%ч. . V \\
\hline $\begin{array}{l}\text { Jumping both } \\
\text { legs inside the } \\
\text { hexagonal } \\
\text { form }\end{array}$ & Second & $19 . .91$ & 1.817 & $1 \& .77 \mathrm{~V}$ & $\cdot .190$ & $\varepsilon . \varepsilon Y Y$ & *10.^9\& & $\%$ \%r.IA \\
\hline $\begin{array}{c}\text { Robe } \\
\text { jumping }\end{array}$ & No. & $r .0 . \varepsilon$ & $\cdot .111$ & \&.AMr & $\cdot . \vee 1 \wedge$ & 1.rvq- & *o.rs & ד ד. \\
\hline
\end{tabular}

(T) Table value at morale level $0.05=2.093$

Results of table (12)

shows that there statistically significant differences between the before \& after measurements of the experimental group in the coordination abilities studied in the research in favor of the after measurement, as (T) calculated values more than its table values at morale level (0.05). The researcher sees that the coordination abilities are a group of general and stable regulators of control \& direction operations; they direct the performance in the first place and controls it. So, they have a close and mutual connection with the motor skills. They appear clearly in the form, method and speedy acquisition and learning of new skills and using them in a suitable way. Also they appear through the degree of 
mastering the skill performance aimed to acquire and to economize in the exerted effort during the performance. Accordingly, using the qualitative coordination abilities during learning is considered the basis of training on the skill performance (the technical performance) and improving it if it was designed well depending on bases and methods of coordination abilities. Because these abilities are one of the conditions of the effective performance that affect many skills and in the same time they are part of the skill was they help in achieve a lot of skill performance aims in water ball sport. Therefore, training on the coordination abilities in the skill direction is considered important before and during the skill performance learning, through these coordination abilities the junior is enabled to learn effectively and improve his skill performance and use his motor stock in the best way to achieve through what he mastered of skills.

This agrees with what Essam Eldin Abdel Khalek (2005) referred to that the coordination abilities contribute in the composing of the total movement of small movements in an coordinated way. If these abilities work was coordinated, the highest level of desired general motor coordination can be achieved in the motor performance in order to achieve the motor skills. (189: 2)

\section{Table (13)}

The significance differences between the two averages of the before \& after measurements of the experimental group in same basic skills and knowledge acquisition studied in the research

\begin{tabular}{|c|c|c|c|c|c|c|c|c|c|}
\hline \multirow{4}{*}{ 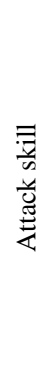 } & \multirow[t]{2}{*}{ variables } & \multirow[t]{2}{*}{$\begin{array}{c}\text { Measure } \\
\text { unit }\end{array}$} & \multicolumn{2}{|c|}{$\begin{array}{c}\text { Before } \\
\text { measurement }\end{array}$} & \multicolumn{2}{|c|}{$\begin{array}{c}\text { After } \\
\text { measurement }\end{array}$} & \multirow[t]{2}{*}{$\begin{array}{l}\text { Difference } \\
\text { average }\end{array}$} & \multirow[t]{2}{*}{$\begin{array}{c}(\mathrm{T}) \\
\text { value }\end{array}$} & \multirow[t]{2}{*}{$\begin{array}{l}\text { Improvement } \\
\text { rates }\end{array}$} \\
\hline & & & M/ & $\mathrm{D} \pm$ & $\mathrm{M} /$ & $\mathrm{D} \pm$ & & & \\
\hline & $\begin{array}{l}\text { The skill of } \\
\text { standing in } \\
\text { deep water }\end{array}$ & Degree & r. $1 \leqslant 0$ & - . & r.\&vi & $.0 \leqslant 9$ & 1.rYY- & $* 9.111$ & $\%(71 . \wedge r$ \\
\hline & $\begin{array}{c}\text { The skill of } \\
\text { holding \& } \\
\text { catching } \\
\text { the ball }\end{array}$ & Degree & r.or & 政 & r.\&rY & $.0 Y \varepsilon$ & $1 . r v 9_{-}$ & $*_{V . \wedge \leqslant r}$ & $\%$ TV. IV \\
\hline
\end{tabular}


Table (13)

The significance differences between the two averages of the before \& after measurements of the experimental group in same basic skills and knowledge acquisition studied in the research $\mathrm{N}=\mathbf{2 0}$

\begin{tabular}{|c|c|c|c|c|c|c|c|c|c|}
\hline \multirow{2}{*}{ 总 } & \multirow[t]{2}{*}{ variables } & \multirow{2}{*}{$\begin{array}{c}\text { Measure } \\
\text { unit }\end{array}$} & \multicolumn{2}{|c|}{$\begin{array}{c}\text { Before } \\
\text { measurement }\end{array}$} & \multicolumn{2}{|c|}{$\begin{array}{c}\text { After } \\
\text { measurement }\end{array}$} & \multirow[t]{2}{*}{$\begin{array}{c}\text { Difference } \\
\text { average }\end{array}$} & \multirow[t]{2}{*}{$\begin{array}{c}(\mathrm{T}) \\
\text { value }\end{array}$} & \multirow[t]{2}{*}{$\begin{array}{l}\text { Improvement } \\
\text { rates }\end{array}$} \\
\hline & & & M/ & $\mathrm{D} \pm$ & $\mathrm{M} /$ & $\mathrm{D} \pm$ & & & \\
\hline & $\begin{array}{c}\text { The skill of } \\
\text { swimming } \\
\text { with the } \\
\text { ball }\end{array}$ & degree & r. rrA & rro. & r.vru & $.0 \leqslant 1$ & $1 . £ 94-$ & $*_{1} \cdot . v r 4$ & $\%$ \%.1. \\
\hline & $\begin{array}{l}\text { Passing } \\
\text { skill }\end{array}$ & degree & r...l & $.01 r$ & r.rvA & $\because$ VAr & 1.rVV- & *v.oor & $\%$ \%.Ar \\
\hline & $\begin{array}{c}\text { Aiming } \\
\text { skill }\end{array}$ & degree & r. YVr & $.7 V 4$ & r.vva & .070 & $1.0 .7-$ & *IE.rYr & \% \\
\hline & $\begin{array}{l}\text { Knowledge } \\
\text { acquisition }\end{array}$ & degree & ro.10. & $1.9 \mathrm{YV}$ & \&1. YO. & r.va & $10 .\{\cdots-$ & $*_{Y .} \cdot$ rq0 & $\% .09 .7$ \\
\hline
\end{tabular}

(T) Table value at morale level $0.05=2.093$

The results of table (13) show that there are statistically significant differences between the after \& before measurements of the experimental group in some basic skill and the knowledge acquisition level in favor of the after measurement as (T) calculated values were bigger than its table values at morale level (0.05).

The researcher attributes this improvement of the experimental group personnel to using the suggested educational program which helped in raising the interest of the learner and motivating him to exert an effort in learning and overcome his feeling of boredom and helped him to well understand the skills and absorb them in a better way which participated in improving the performance level of some attack skills in water ball sport studied in the research. The program also paid attention to dividing the skill into small parts in light of its logical sequence in an organized and sequenced way and associated them in a linear way to form an image. This helped the learner to form a clear image of the skill in addition to the concentration and understanding each part and learn it in an easy way.

The same previous table also shows that there are 
statistically significant differences between the after \& before measurements of the experimental group in the knowledge acquisition level of attack skills in water ball sport in favor of the after measurement. The researcher attributes this to the suggested program using the coordination abilities which work on developing the knowledge aspect; usually the individual accumulate the information in his memory and when he needs to use them he retrieve them which is known as selffeedback. In this teaching method, direct and indirect information and knowledge about the skills studied in the research are introduced to the learners. This result agrees with the studies' results of Fayza Shebl (2001) (3), Naglaa Abdel Moneim (2003) (9), Tarek Elnosery (2013) (18), that assure the importance of using teaching methods in increasing the knowledge acquisition of the learners. Alfred (2001) refers that acquiring theoretical information and knowledge contributes in increasing the learning effectiveness, and that the learner's performance degree of the skill depends on the learner's ability to explain the skill well concerning the right positions of each of the body parts during the learning process. (128: 11)

Thus, the research hypothesis which states that " there are statistically significant differences between the before and after measurements of the experimental group in the basic skill performance level and knowledge acquisition in water ball sport and is in favor of the after measurement" is proved right. Conclusions:

In light of this research results and in the limits of research plan and procedures, we conclude the following:

1- Merging the coordination trainings with the skill trainings achieved effectiveness in developing the skill level of research sample.

2- Coordination trainings have a positive effect on developing the performance level of skill tests of Sporting Club water ball juniors under 16 years.

3- Developing the skills tests moves towards the ascending direction as a result of the continuous training on the coordination trainings. 
4- Coordination trainings increase the juniors' motor stock which appeared in the performance of complex tests.

5- The experimental group superiority in the knowledge acquisition level studied in the research.

\section{Recommendations:}

In light of the research aims and results and in the limit of research sample and in addition to executing the coordination trainings in this research and results registration, the researcher recommends the following:

1- The necessity of paying attention to learning and training the coordination abilities and to include them in clubs' programs of water ball sport.

2- $\quad$ Applying the suggested trainings on different and similar age stages and players.

3- To perform a similar study on the other athletic activity and on different samples.

\section{References:}

\section{First: Arabic References:}

1- Tarek Khalil algamal (2008): the effect of the special coordination abilities on the skill performance level of Field Hokey juniors, the $1^{\text {st }}$ International Conference of physical education, sport and health, $1^{\text {st }}$ issue, Kuwait.

2- Essam Eldin Abel Khalek (2005): the athletic training (theories \& application), edition 12, Dar Elmaaref, Cairo.

3- Fayza Mohammed Shebl (2005): the effect of a suggested program using the dissimilar method on learning some volley ball skills of Physical Education Faculty female-students in Tanta, an unpublished $\mathrm{Ph}$. D thesis, Physical Education Faculty, Tanta University.

4- Mohammed Hamdy Abdel Hady (2009): the effect of a training program to develop some coordination abilitieson the effectiveness of spin skill and the time of crawl swimming on the back, an unpublished Master thesis, Physical Education faculty for males, Mansoura University.

5- Mphammed Sobhy Hassanin (2001): measurement and correction in physical education and sport, edition 4, part 1, Dar Elfekr Elaraby, Cairo.

6- Mohammed Ali Elkott (2002): the brief in water sports, $1^{\text {st }}$ edition, the Arab center for publication, Zagazig. 
7- Mohammed Lotfi

Hassanin (2006): the athletic achievement and training work rules, an application vision, Elketab Center for publishing, Cairo.

8- Makarem Helmy Abu Harga, Mohammed Saad Zaghlol (1996): teaching methods and practical education in the field of scholar physical education, edition 2, Dar Heraa, Almenyia.

9- Naglaa Abdel Monem Mohammed (2003): the effect of using both methods of application by peers direction and the multi-levels selfapplication on some motor and knowledge variables of volley ball in the lesson of physical education for the secondary school female-students, an unpublished $\mathrm{Ph}$. D thesis, Physical Education Faculty in Port Saied, Suez Canal University.

10- Hadeer Saied Abdel Azeem (2010): the effect of using unilateral fins on some functional \& coordination abilities of pool buds, magazine of physical education researches, physical education faculty for males, Zagazig university, volume 44, issue 83, August.

\section{Second: Foreign References:}

11. Alfred, B., (2001): Problems the commands styles in physical education, the Journal of educational Research, Vol. 114, No. 40.

12. Agnieszka, Jadach, (2005): Connection between particular coordination motor abilities and game efficiency of young female handball players. www.awf.krakow.pl/jedn/gryze sps.

13. Glasauer, G., (2003): Koordinationstraining im Basketball. Von Ressourcen über Anforderungen zu Kompetenzen, Dissertation, Verlag Dr. Kovac, Hamburg.

14. Hohmann.A., Lames,M., Letzelter, M., (2002): Einfuhrung in die Training Swissenschaft, (2.aufl)., Limpert, Wiebelsheim.

15. Mathews

(1996):

Measurement in physical education 5th ed., Saunders com- Pony, Philadelphia, London.

16. Reigl, M., (2003): Effects of motor games applied in lower primary physical education on the changes of coordination abilities of lower primary school children, faculty of physical education and sport sciences semmelwais university, Budapest. 
17. Singer, M., (1995): effectiveness of coordination Motor Learning and Human training in sport, department of performance and application to anthropocentricity, university motor skills, Macmillan Publishing co., New York.

of physical education in Krakow, Poland.

18. Tarek,. M,. Elnosery (2013): The Effect of coordination abilities on learning Some Attack, Defense and cognitive skills in Handball, The International Edition of the Official. Peer. Reviewed Journal of the Faculty of Physical Education, Abu Qir, Alexandria University.

19. Vladimir Lyakh, 20. Zak, St., Duda, H., (2003): Level of Coordinating Ability but Efficiency of Game of Young Football Players.

Third: National Net for Information:

21. www. Encyclopeda.com: Water Polw. The Columbia Encyclopedia. Sixth edition 2008. Encyclopedia .com 9 Aug. 2009

(2006): The concepts and 